\title{
DISTANCE LEARNING DURING THE COVID-19 PANDEMIC: STRENGTHENING OF CHARACTER, PRODUCTIVITY,AND STEM COMPETENCY
}

\author{
Chaerul Rochman ${ }^{1}$, Dindin Nasrudin ${ }^{2}$, Rokayah $^{3}$, Sri Mulyani $^{4}$, Catherien Suci Ramdhini Pertiwi ${ }^{5}$, \\ Ginanjar $^{6}$ \\ ${ }^{1,2}$ Program Studi Pendidikan Fisika, UIN Sunan Gunung Djati Bandung, Jawa Barat, Indonesia \\ ${ }^{3}$ STKIP Sebelas April Sumedang, Jawa Barat, Indonesia \\ ${ }^{4}$ MI Al Falah, Jakarta Timur, DKI Jakarta, Indonesia \\ ${ }^{5}$ SMP Ar Rafi Drajat, Bandung, Jawa Barat, Indonesia \\ ${ }^{6}$ SMA Karya Budi, Kabupaten Bandung, Jawa Barat, Indonesia \\ 1'chaerulrochman99@uinsgd.ac.id
}

DOI: https://doi.org/ 10.21107/jps.v7i2.8261

\begin{abstract}
This study aims to reveal the impact of distance learning during the Covid-19 pandemic on Science Technology Engineering and Math (STEM) competence, productivity, and students' character. This research uses mixed methods. The questionnaire instrument consists of STEM components, Learning Products, and character profiles obtained from Elementary School/Madrasah Ibtidaiyah, Junior High Schools, and Senior High Schools in Jakarta and Bandung. Furthermore, the data were analyzed, and it was concluded that the performance of all the variables studied had varying degrees. Besides, STEM literacy skills are closely related to learning productivity and character building of students at all levels of education. Therefore, distance learning after the Covid-19 pandemic needs to be planned well and considers the level of STEM literacy and character content clarity.
\end{abstract}

Keywords: Characters, Distance Learning, Productivity, STEM

\footnotetext{
${ }^{1}$ Corresponding Author
} 


\section{Introduction}

The whole world has experienced shifts in various aspects of life due to Covid-19 pandemic. The education component includes institutions that experience various extreme changes (Andrews et al., 2020; Priatna, 2020; Srinivasan, 2020; Marziali et al., 2020). In the educational aspect, an order immediately changes the various components of education, especially the learning process and practice (Karim, 2016). Initially, the learning process was centered at school with face-to-face changes to be done at home. Learning media has changed from using models, posters, and props provided in schools, now computer technology devices and cellphones must be used. In the end, distance learning is one of the solutions for the continuity of the current learning process. As a result, everyone must have the competence to manage various existing facilities on existing technology devices such as WhatsApps video calls, and Google meets, Zoom meeting, Classroom, and others (Arthur et al., 2020; Berry \& Hughes, 2020; Erfan et al., 2020. ; Gunawan, 2020; Hastini et al., 2020; Sanjata, 2020; Yamin \& Syahrir, 2020). This condition encourages students to be more creative so that the learning process can produce a product. So they must be able to adapt and acquire communication technology skills. (Chesser et al., 2020; Rostikawati et al., 2020; Zainuddin, 2020). Lessons relevant and support this adaptation include learning Science, Technology Engineering, and Mathematics (STEM). However, it is still not believed whether the application of this learning will affect students' learning productivity and character. Furthermore, the good practice of STEM mastery, productivity, and character will help students think creatively and be better prepared to face the "New Normal" period (Chesser et al., 2020; Farach, Kartimi, \& Mulyani, 2019; Rostikawati et al. al, 2020; Sarnita and Fitriani, 2019; Zainuddin, 2020).

Research related to the impact of Covid-19 on various aspects of education and entering the New Normal era is important. Several studies have concluded that students' ability to science and technology is a prerequisite for being able to adapt to new learning in the future (Aditia et al., 2020; Almanthari et al., 2020; Hasanah et al., 2020; Pakpahan \& Fitriani, 2020; Pujiati, 2019; Purwanto et al., 2020; Qadir Al-Fuqaha, 2020; Sintema, 2020; Surya \& Rizal, 2019; Syamsuar \& Reflianto, 2019; Yamin, 2020). The information technology device most widely used by students is the Android mobile phone. Consequently, students must be skilled at utilizing various features of various communication tools (Anwas, 2019). Students must be skilled at recording sound and images and sending them to teachers as learning products (Bilyalova et al., 2020; He et al., 2020; Prayogi, 2020; Sutisna, 2020). Even though students' technical skills, the learning process in new normality will also affect the productivity and character of students (Jamaluddin et al., 2020; Pujilestari, 2020; Setiawan and Mufassaroh, 2020). Different education levels will affect STEM abilities, productivity, and student character (Arifin, 2020; Azizah et al., 2019; Bakhtiar, Kurniati \& Nayazik, 2020; Permatasari, 2018).

The information and some research findings indicate the importance of evaluating learning during a pandemic. The components that are still not widely disclosed include the STEM ability profile, the ability to produce products, and students' character. The disparities in students' education levels against the three variables above have not been revealed. Therefore, this study explores how to profile these components and analyze the simple relationship between the three components. The purpose of this study was to reveal the profiles and comparisons of STEM competencies in three groups of students, the relationship between STEM competencies and products, and the character of students. Finally, this research is expected to provide new findings to formulate a hypothetical model of learning after the Covid-19 pandemic. The novelty value of this study's findings is a distance learning model during the "new normal" at various levels of education by taking into account the diversity of STEM abilities, productivity, and student character.

\section{Research Methods}

The research method used is descriptive quantitative non-parametric, and qualitative. Researchers collaborated with three teachers from different levels in collecting data, namely Madrasah Ibtidaiyah teachers, junior high schools, and high school teachers in Bandung and Jakarta. Respondents who are actively involved are students from the three school levels, as in table 1.

Table 1. Respondents

\begin{tabular}{ccccc}
\hline \multirow{2}{*}{ No } & \multirow{2}{*}{ Level } & \multicolumn{2}{c}{ Gender } & \multirow{2}{*}{ Total } \\
\cline { 3 - 4 } & & Boys & Girls & \\
\hline 1 & Elementary School & 17 & 15 & 32 \\
2 & Junior High School & 18 & 14 & 32 \\
3 & High School & 16 & 20 & 36 \\
\hline & Total & 51 & 49 & 100 \\
\hline
\end{tabular}

The instrument used was a list of recorded student products authentically by filling in a checklist that was weighed and scored by the 
teacher. The follow-up instrument is triangulation in the form of a list of questions to explore respondents' information. There are 3 (three) variables used, namely the ability of Science Technology Engineering and Math (STEM), productivity (learning products), and character, as shown in table 2.

Table 2. Component aspects of STEM ability, productivity, and character

\begin{tabular}{lll} 
No. Component & \multicolumn{1}{c}{ Aspects } \\
\hline 1 & STEM Ability & $\begin{array}{l}\text { operating a smartphone/laptop, } \\
\text { knowing the scientific aspects } \\
\text { of features, recording audio, } \\
\text { recording video, sending data, } \\
\text { the ability of aspects of } \\
\text { mathematical dimensions }\end{array}$ \\
& & $\begin{array}{l}\text { Image/report quality, audio } \\
\text { recording quality, video } \\
\text { recording quality, report } \\
\text { comment/analysis quality, and } \\
\text { distance learning procedure }\end{array}$ \\
& & capability \\
& & $\begin{array}{l}\text { honesty, hard work/earnestness, } \\
\text { care, accuracy, and compliance } \\
\text { during distance learning }\end{array}$ \\
& &
\end{tabular}

Data processing is carried out based on several stages. First, giving a score or assessing all aspects of the three components (variables) being measured (Pertiwi et al., 2019). The range of scores used is $3-6$ (qualification: less, moderate, good, and very good). Second, calculate the average and total score based on aspects and components as well as respondents. Third, calculate the average score based on gender. Fourth, comparing the profiles of the three components of the three levels of education and calculating the simple relationship between the three groups of variables. Fifth, calculating the relationship between STEM components with Product and Character by calculating nonparametric correlation. Sixth, presenting the compilation of calculation results in graphical form. Finally, triangulation was carried out, namely exploring the data and respondents of the male and female groups who had the lowest score compared to their group's average score.

\section{Result and Discussion}

This section will present the STEM competency profiles, products, and student characters based on the data obtained-a comparison of the relationship between STEM components with student products and characteristics. In the end, a triangulation description is also presented for some of the respondents whose scores were the lowest compared to the group scores. The competency profiles of all respondents by level are presented in Figure 1.

Figure 1 shows the distribution of students' competency comparisons in the elementary, junior, and High School groups varied. The averages for the three components were: 5.56, 5.40, and 4.67 (STEM) respectively; 5.31; 5.27, and 4.91 (Products), and 5.24, 5.44, and 4.83 (Character). Overall, high school students showed the lowest average competency of all components, namely 4.80. In the STEM component, the lowest average score at all levels, respectively, lies in the aspect of operating a smartphone/laptop or tablet. For product components, all levels of the lowest average score are in the activity's video aspect. Meanwhile, the lowest average score for character components is in the aspect of communication skills.

STEM components, products, and characters at all levels vary. In the STEM component, of the 6 (six) aspects studied, the aspect of operating a smartphone has the lowest average score. For all groups, operating communication devices are part of engineering skills (a part of STEM) (Bilyalova, Gilyazeva, Polkina, 2020). Although high school students showed a low average score, the types and characters of menu operations in remote learning were different. There are several new and more complex applications used by high school students when learning during the Covid-19 Pandemic. The difficulty level of operating communication tools for students at each level will vary. The simple application can be operated easily by elementary school students.

Student activities that produce products in learning images (visuals) are of low quality (Rokayana, 2017). There are some difficulties for students in drawing, such as making sketches and choosing suitable colors. Studying other people's pictures often and how to choose colors can help students produce quality images. Students at the junior high school level do better for all competency components. The ability to operate communication devices to produce digital products is quite evenly distributed among elementary level students (Akhmad, 2020; Kiili et al., 2020; Lazonder et al., 2020; Manalu et al., 2020; Mishra, 2020; Parasyanti et al., 2020).

The aspects with a high average score (5.7) are aspects of honesty and response to teachers during distance learning in the character component. The teacher's honest character and responses to distance learning with the help of 
communication tools can be observed by the teacher directly. So that students communicate in the learning process authentically (Lazonder et al., 2020). High school students are the lowest at the three groups' average scores (under 5). The lowest score in the group of high school students can be seen in attention and response (average score of 4.6). The higher the level, the smaller the level of student attention and response (Lestariningrum, 2014; Patandung, 2017). The existence of various character components indicates that Distance learning during the Covid-19 Pandemic can form strong student character (Asanov et al., 2020; Burhanudin et al., 2020; Drane et al., 2020; Jamal, 2020; Sandars et al., 2020; Setiawan, 2020). Attention and response aspects during the home study are strong aspects (Darmalaksana et al., 2020; Effendi et al., 2020; Satriah et al., 2020; Setiawan \& Mufassaroh, 2020; Subarto, 2020).

The profile of the relationship between students' STEM abilities with the productivity and character components can be shown in Figure 2. Figure 2 shows the relationship between the average STEM score and the Product and Character component variables at all levels varied. In simple terms, the relationship between STEM competencies with product components and the highest character occurs in the high school student group (coefficient above 0.9). Meanwhile, the lowest relationship was found in the junior high school student group of 0.10 , namely between STEM and character (0.10). The same relationship (0.69) was found in the elementary and junior high school student groups, namely the relationship between the STEM components and the product.

The high correlation coefficient between STEM on products and character in high school students shows a very significant relationship compared to the junior high school group. This shows that high school students' performance in the STEM aspect is in line with the productivity and character formed during distance learning in the strong category. Meanwhile, the relationship between STEM components and productivity in the junior high school group is similar. It can be assumed that the relationship between STEM components and productivity is as strong in the medium category (Khairunisa, 2017; Yazdi, 2012;). Students' ability to understand and record audio or video will be in line with the quality of their audio and video products (Gowasa, 2019; Hadi, 2017). This means that science and technology skills are in line with students' digital products (Jauhariyyah, 2018; Sai, 2017).

The lowest relationship between STEM components occurs at the junior high school level, namely, STEM and Character. This relationship shows that the characters formed in students are less related to their STEM abilities. Most students with high attention/response aspects came from groups of students with low to moderate STEM. Likewise, the higher the average score of honesty is not in line with the higher the quality of the students' audio and visual products. Based on the analysis and confirmation with some of the previous studies' results, there is a relationship between STEM abilities, products, and student character. The relationship between the three components at each level shows variation. This shows that students have varied characters. Furthermore, the provision of STEM abilities, types of assignments or bills, and characterbuilding must vary.

Some data have a low average score from all respondents obtained compared to the group score, as in table 3. Table 3 shows the six respondents who have the lowest average score compared to the group score. For the six respondents, an in-depth study was conducted as a triangulation step. The lowest respondent from each group is represented by a group of men and one woman each. All of the lowest respondents have an average score of less than five.

The lowest score of all respondents is owned by DOM, junior high school students, respectively, in the Character component (3.5) or has a difference of 1.7 from the component score (5.25). TNF, high school students, have an average score on the STEM component of 3.5 or have a difference of 1.17 from the component score (4.67). Junior high school students with code HH, although the STEM components and products are the lowest $(4,3$ and 4,5). However, he/she has the maximum average score for the character components, which is 6. This shows that even though $\mathrm{HH}$ has difficulty with the STEM and Product components. However, distance learning gave positive reinforcement to his character. 


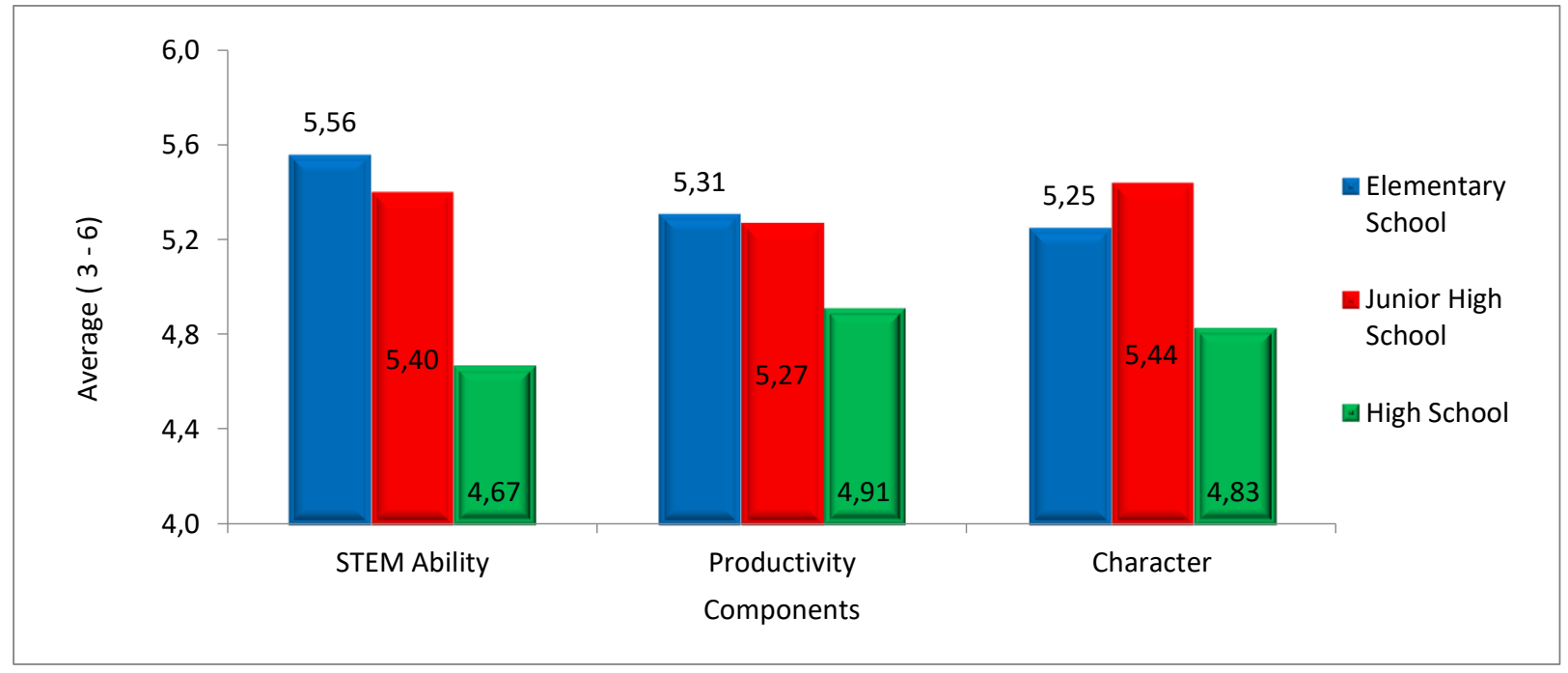

Figure 1. Profile Students' Competency

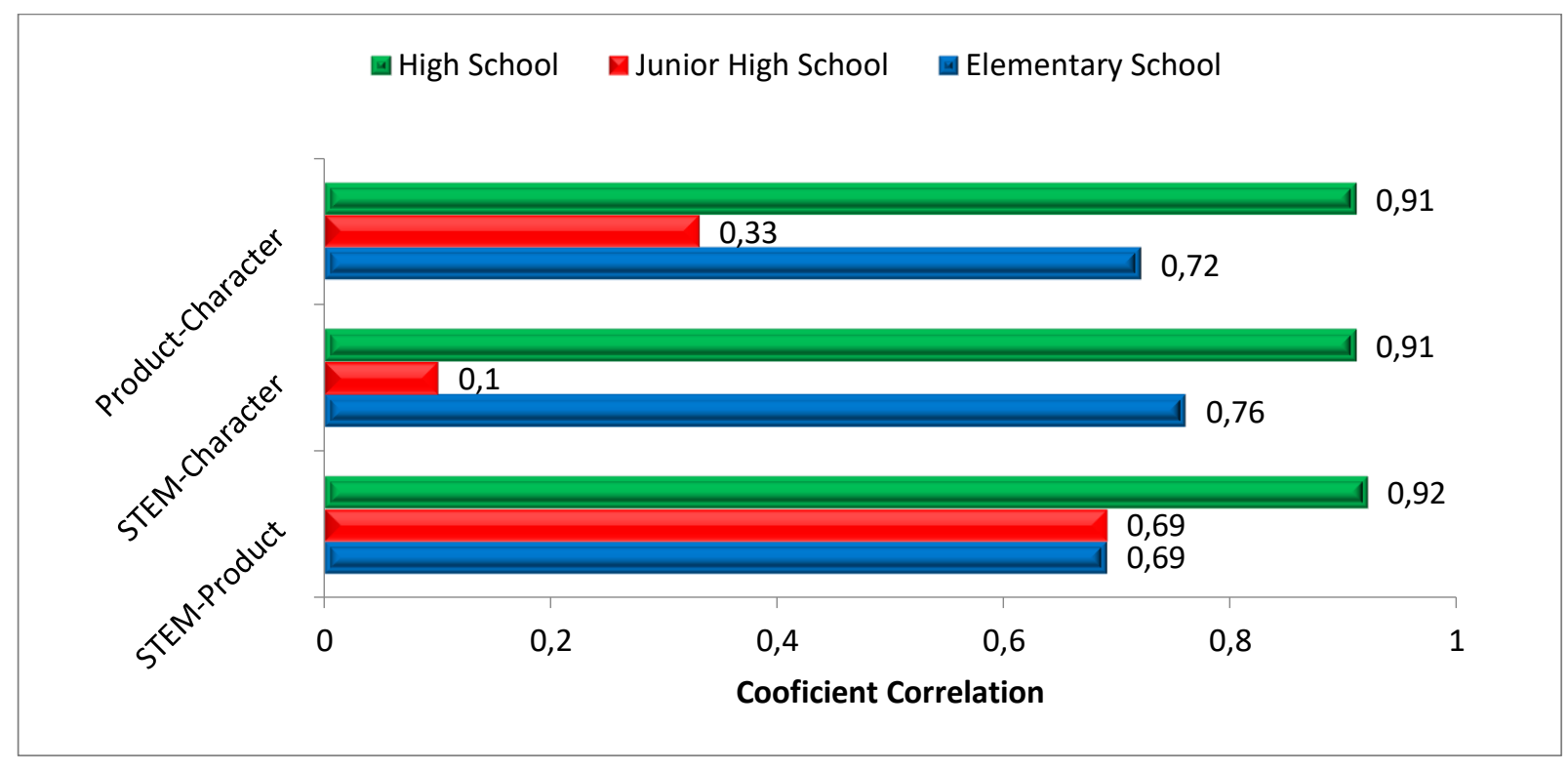

Figure 2. Correlation between STEM ability, Productivity, and Character

Table 3. The lowest average score

\begin{tabular}{|c|c|c|c|c|c|c|}
\hline \multirow{2}{*}{ No } & \multirow[t]{2}{*}{ Level } & \multicolumn{5}{|c|}{ Respondents } \\
\hline & & Code Res. & STEM & Product & Character & Cumulative \\
\hline 1 & \multirow{3}{*}{$\begin{array}{l}\text { Elementar } \\
\text { y School }\end{array}$} & DOM (L) & 4,6 & 3,7 & 3,5 & 3,91 \\
\hline 2 & & $\mathrm{~N}(\mathrm{P})$ & 5,6 & 4,7 & 4,5 & 4,91 \\
\hline & & Average & 5,56 & 5,31 & 5,25 & \\
\hline 3 & \multirow{3}{*}{$\begin{array}{l}\text { Junior } \\
\text { High } \\
\text { School } \\
\end{array}$} & HSI (L) & 5,2 & 4,8 & 4,5 & 4,81 \\
\hline \multirow[t]{2}{*}{4} & & $\mathrm{HH}(\mathrm{P})$ & 4,3 & 4,5 & 6,0 & 4,94 \\
\hline & & Average & 5,40 & 5,27 & 5,44 & \\
\hline 5 & High & TNF (L) & 3,5 & 3,8 & 3,7 & 3,70 \\
\hline \multirow[t]{2}{*}{6} & School & ORPN (P) & 4,0 & 4,2 & 4,2 & 4,10 \\
\hline & & Average & 4.67 & 4,911 & 4,83 & \\
\hline
\end{tabular}


The DOM is having difficulty finding solutions to problems because there is not enough support. The steps he/she took were increasing support and assistance from people other than his parents. Another difficulty is making images and video products. Existing facilities in his residence do not support both of these activities. To overcome this, ask for help other than their parents. Since childhood, DOM has had family problems. While at school, he/she was helped by his teachers. However, when distance learning took place, the DOM encountered many obstacles. The parents who live with him/her are busy working, only occasionally Work from Home (WFH). DOM has no personal communication tools. Teachers can encourage DOM to be more open with friends, parents, teachers, and people around to improve their skills (Wang, 2020).

Respondent N, he/she has declared a doctor to have a disease. Since in the low class, $\mathrm{N}$ has low self-confidence (inferior). Parents and teachers often provide motivation. $\mathrm{N}$ had difficulty finding solutions to problem-solving. He/she felt inadequate. So that the task he completed was just a "duty abortion." The presence of friends and teachers can be a motivator for him. However, during distance learning, $\mathrm{N}$ seems to have lost his "motivator." Therefore, the teacher encourages $\mathrm{N}$ to change his "mindset, that is, even though there is a disease in him, he is capable of being like other children (Effendi et al., 2020; Ibáñez, 2020). N is encouraged to gain insight through reading books or watching programs whose content is about people with disabilities' struggles. Another difficulty is making activity videos. $\mathrm{N}$ completed just as an abort obligation. No maximum effort was made. The thing that is pushed to $\mathrm{N}$ is an open mindset that completing a task is not just done, but is a thought that is done in earnest and optimal efforts (Akhmad, Masrukhi, Indiatmoko; 2020; Anggraini, 2020). In the character component, $\mathrm{N}$ feels he is different and less than his friends. The steps that will be taken are to encourage $\mathrm{N}$ to have the courage to mingle with friends. Dare to appear not only in class, participate in various extracurricular activities to express interests and talents (He, 2020). Opening insights and mindsets that children with "deficiencies" can still show their strengths (Capurso et al., 2020).

HSI has difficulty in drawing/coloring (product components) because it easily gives up. $\mathrm{He} / \mathrm{She}$ is a child with a lack of effort. The ability is there, but he/she does not like challenging things. The step that he did was to make a simple picture. However, if a new spirit emerges, he/she will try to get the best results. HSI's memory is weak. HSI includes having an audio rather than visual learning style (Classroom, Google Meet, $\mathrm{VC}$, etc.). If he/she gets a visual explanation of learning, he will not understand much. But if he/she is asked to both listen and understand it him/herself, he is quick to understand. During learning, he/she prefers while listening to instruments. Characters like daily Tahfidz activities, he/she memorizes them faster by listening to murattal.

$\mathrm{HH}$ has difficulties recognizing and using HP features. He/she also still has difficulty editing photos or videos via cellphone. He/she was confused when he sent the video recorded on his cellphone to upload it in the classroom (transferring it via a data cable). The teacher sometimes asks some of the features and functions of smartphone features. $\mathrm{HH}$ had a hard time recording the video. $\mathrm{He} / \mathrm{she}$ can not operate the picture properly. When doing video recording at the right angle, he/she needs his friend's help. Even in editing, it is still somewhat "rough." However, this child is one of those children who always try to do the job seriously. He/she will continue to try to fix his shortcomings. Usually, when recording a video, he/she will first ask his teacher for permission. If he/she is often late in submitting assignments, so he/she wants his efforts to do better. In addition, we wish there were better developments even though it will take longer. The source asked what he/she did was ask friends, teachers, but through googling.

TNF is among students who have experienced many difficulties in distance learning since the Covid-19 pandemic. New habits that, unexpectedly, caused her/him the enthusiasm to learn to decline drastically (Irawati, 2019). Many other students, in general, experience this. The Covid-19 pandemic can reduce motivation and the quality of learning outcomes. Some of it is caused by difficulties in mastering information and communication technology (IT). For example, TNF experienced difficulties in the recording process due to the camera's quality and was not used to speaking while being recorded. Partly, students have not been able to adjust to various non-academic obstacles.

Likewise, ORPN students experience difficulties in all components, both STEM, distance learning products, and character building. ORPN does not have a cellphone, so his ability to operate cellphones is not very smooth and is not used to it, so that it becomes an obstacle in carrying out distance learning. The learning process also did not have friends who were close to home, so studying together cannot be possible? 
Environmental factors that are less supportive can affect creativity and fighting power (Fajriah, 2018; Widiyaningrum and Hamalik, 2016). The operation of a smartphone that is still stiff becomes an additional burden. The fear of operating a cellphone, such as fear of pressing a wrong button, fear of being damaged, becomes a trigger for distracted learning concentration. More focused on the competencies that will be achieved in the distance learning process. The process of implementing distance learning is hampered because of the difficulty of communicating. So, the things that must be done are later than the otherscommunicating better in the learning process, so that things that need to be done during the process of implementing distance learning can be done well. The efforts made by the teacher are conveyed individually and gradually. Understanding and literacy are easy ways of learning when distance learning continues. The teacher motivates by appreciating every result of the TNF and ORPN students, no matter how small. In addition, the teacher encourages these students to get used to finding information that is the latest, interesting, and relevant to learning materials.

Based on the analysis of descriptions and discussions, problems and solutions related to STEM, products, and student character can be elaborated. Distance learning (online) during the Covid and New Normal pandemic needs to start with STEM literacy (Rochman and Rokayah, 2019; Sintema, 2020). Important aspects of STEM skills such as operating a cellphone, recording audio and visuals should be part of the learning; in this distance learning, teachers and parents' role as companions (Satriah et al., 2020). The results of STEM learning accompaniment are digital products inherent to the success of distance learning (Setiawan, 2020; Setiawan \& Mufassaroh, 2020). This distance learning success will be demonstrated by a lot and the improvement in the quality of student products. It also shows the effectiveness of online learning supported by STEM literacy (Choy, Yim, \& Tan, 2020; Drane, Vernon, \& O'Shea, 2020; Pertiwi, Rochman, and Mansyur, 2019). Another consequence is the effectiveness of online learning related to the process of forming and enhancing student character (Asanov et al., 2020; Burhanudin et al., 2020; Tran et al., 2020). Therefore, distance learning in the post-Covid-19 period is a learning strategy solution for teachers, school leaders, and parents (Darmalaksana, 2020; Praherdhiono et al., 2020; Purwanto et al., 2020; Qadir \& Al-Fuqaha, 2020; Sandars et al., 2020; Subarto, 2020).

\section{Conclusion}

Distance learning during the Pandemic and post-pandemic times needs to be implemented by providing a syntax that considers and supports the differences in STEM abilities, productivity, and character of students. Students must master Literacy Science Technology Engineering and Math (STEM) according to their level. Distance Learning can increase student productivity more creatively. Students at various levels of education must pay attention to academic and non-academic characteristics, which is done gradually. For that, we need assistance to students so that their personality and character can grow optimally. This study recommends an integration model between STEM literacy, Learning Products, and Character through flexible syntax. Henceforth, it is necessary to study the importance of practical and sustainable assistance to students.

\section{References}

Akhmad, Y., Masrukhi, M., \& Indiatmoko, B. (2020). The Effectiveness of the Integrated Project-Based Learning Model STEM to improve the Critical Thinking Skills of Elementary School Students. Educational Management, 9-16.

Almanthari, A., Maulina, S., \& Bruce, S. (2020). Secondary School Mathematics Teachers' Views on E-learning Implementation Barriers during the COVID-19 Pandemic: The Case of Indonesia. Eurasia Journal of Mathematics, Science and Technology Education, 16(7), em1860.

Andrews, J. L., Foulkes, L., \& Blakemore, S. J. (2020). Peer influence in adolescence: Public-health implications for COVID19. Trends in Cognitive Sciences.

Anggraini, R. (2020). Pengaruh Model Pembelajaran STEM (Sains, Technology, Engineering, And Mathematics) Terhadap Kemampuan Penalaran Matematis Siswa Ditinjau Dari Kemampuan Berpikir Logis Siswa Kelas X Ipa Sma Negerii 9 Bandar Lampung Tahun Pelajaran 2019/2020 (Doctoral Dissertation, Uin Raden Intan Lampung).

Anwas, O. M. (2019). Kontribusi Pemanfaatan Teknologi Informasi dan Komunikasi di Daerah Tertinggal Contribution of Information and Communication 
Technology Utilization in The Underdeveloped Area. Jurnal Teknodik, 17(3), 018-028.

Arifin, N. (2020). Efektivitas Pembelajaran STEM Problem Based Learning Ditinjau dari Daya Juang dan Kemampuan Pemecahan Masalah Matematis Mahasiswa PGSD. JPMI (Jurnal Pendidikan Matematika Indonesia), 5(1), 3138.

Arthur-Nyarko, E., Agyei, D. D., \& Armah, J. K. (2020). Digitizing distance learning materials: Measuring students' readiness and intended challenges. Education and Information Technologies, 1-16.

Asanov, I., Flores, F., Mckenzie, D. J., Mensmann, M., \& Schulte, M. (2020). Remote-learning, Time-Use, and Mental Health of Ecuadorian High-School Studentsduring the COVID-19 Quarantine. World Bank Policy Research Working Paper, (9252).

Azizah, W. A., Sarwi, S., \& Ellianawati, E. (2019). Pendekatan STREAM terhadap peningkatan Kemampuan Berpikir Kritis Siswa Sekolah Dasar. In Prosiding Seminar Nasional Pascasarjana (PROSNAMPAS) (Vol. 2, No. 1, pp. 461-468).

Bakhtiar, I., Kurniati, L., \& Nayazik, A. (2020). Effectiveness of STEM (Science, Technology, Engineering, Mathematics) Approach Towards Mathematics Learning Achievement on Point, Line and Field Material in Three Dimensions. Hipotenusa: Journal of Mathematical Society, 2(1), 1-5.

Berry, G. R., \& Hughes, H. (2020). Integrating Work-Life Balance with 24/7 Information and Communication Technologies: The Experience of Adult: Students With Online Learning. American Journal of Distance Education, 1-15.

Bilyalova, A. A., Gilyazeva, E. N., \& Polkina, G. M. (2020, May). Development of SelfEducational Competence of Students by Means of Digital Educational Technologies. In 2nd International Scientific and Practical Conference "Modern Management Trends and the Digital Economy: from Regional Development to Global Economic Growth"(MTDE 2020) (pp. 201-208). Atlantis Press.
Burgess, S., \& Sievertsen, H. H. (2020). Schools, skills, and learning: The impact of COVID19 on education. VoxEu.org, 1.

Burhanudin, U., Nurulhaq, D., Nandang S, A., \& Fikri, M. (2020). Membangkitkan potensi fitrah belajar pada masa wabah Covid-19 melalui pembentukan mindset driver.

Capurso, M., Dennis, J. L., Salmi, L. P., Parrino, C., \& Mazzeschi, C. (2020). Empowering Children Through School Re-Entry Activities After the COVID-19 Pandemic. Continuity in Education, 1(1).

Chesser, S., Murrah, W., \& Forbes, S. A. (2020). Impact of Personality on Choice of Instructional Delivery and Students' Performance. American Journal of Distance Education, 1-13.

Choy, S. C., Yim, J. S. C., \& Tan, P. L. (2020). A Metacognitive Knowledge, Metacognitive Experience, And Its Effects On Learning Outcomes For STEM And Non-STEM Malaysian Students. International Journal of Advanced Research in Education and Society, 2(1), 1-14.

Darmalaksana, W., Hambali, R., Masrur, A., \& Muhlas, M. (2020). Analisis Pembelajaran Online Masa WFH Pandemic Covid-19 sebagai Tantangan Pemimpin Digital Abad 21. Karya Tulis Ilmiah (KTI) Masa Work From Home (WFH) Covid-19 UIN Sunan Gunung Djati Bandung, 1-12.

Drane, C., Vernon, L., \& O'Shea, S. (2020). The impact of 'learning at home' on the educational outcomes of vulnerable children in Australia during the COVID-19 pandemic.

Effendi, D. I., Lukman, D., Eryanti, D., \& Muslimah, S. R.(2020) Advokasi psikologis bagi masyarakat terpapar pandemi Covid-19 berbasis religious E-Counseling. Advokasi Psikologis Bagi Masyarakat Terpapar Pandemi Covid-19 Berbasis Religious ECounseling.

Erfan, M., Widodo, A., Umar, U., Radiusman, R., \& Ratu, T. (2020). Pengembangan Game Edukasi "Kata Fisika" Berbasis Android untuk Anak Sekolah Dasar pada Materi Konsep Gaya. Lectura: Jurnal Pendidikan, 11(1), 31-46. 
Fajriah, N. (2018). Hubungan Antara Kepercayaan Diri Dengan Kreativitas Belajar Siswa Pada Bidang Studi Ekonomi Di Sekolah Menengah Atas Negeri 1 Sungai Mandau Kecamatan Sungai Mandau Kabupaten Siak (Doctoral dissertation, Universitas Islam Negeri Sultan Syarif Kasim Riau).

Farach, N., Kartimi, K., \& Mulyani, A. (2019). Penerapan Assessment Kinerja dalam Pembelajaran Biologi Berbasis STEM (Science, Technology, Engineering, dan Mathematics) untuk Meningkatkan Keterampilan Proses Sains Siswa Pada Sub Konsep Sistem Indera Kelas XI di MAN 1 Kota Cirebon. Jurnal Ilmu Alam Indonesia, 2(1).

Gowasa, S., Harahap, F., \& Suyanti, R. D. (2019). Perbedaan Penggunaan Media Powerpoint Dan Video Pembelajaran Terhadap Kemampuan Berpikir Tingkat Tinggi Dan Retensi Memori Siswa Pada Mata Pelajaran Ipa Di Kelas V SD. Jurnal Tematik, 9(1), 19-27.

Gunawan, G., Suranti, N. M. Y., \& Fathoroni, F. (2020). Variations of Models and Learning Platforms for Prospective Teachers During the COVID-19 Pandemic Period. Indonesian Journal of Teacher Education, 1(2), 61-70.

Hadi, S. (2017, May). Efektivitas Penggunaan Video Sebagai Media Pembelajaran Untuk Siswa Sekolah Dasar. In Seminar Nasional Teknologi Pembelajaran Dan Pendidikan Dasar 2017 (pp. 96-102).

Hasanah, A., Lestari, A. S., Rahman, A. Y., \& Daniel, Y. I. (2020). Analisis aktivitas belajar daring mahasiswa pada pandemi Covid-19.

Hastini, L. Y., Fahmi, R., \& Lukito, H. (2020). Apakah Pembelajaran Menggunakan Teknologi dapat Meningkatkan Literasi Manusia pada Generasi Z di Indonesia? Jurnal Manajemen Informatika (JAMIKA), 10(1), 12-28.

He, T., Huang, Q., Yu, X., \& Li, S. (2020). Exploring students' digital informal learning: the roles of digital competence and DTPB factors. Behaviour \& Information Technology, 1-11.
Ibáñez, M. B., Portillo, A. U., Cabada, R. Z., \& Barrón, M. L. (2020). Impact of augmented reality technology on academic achievement and motivation of students from public and private Mexican schools. A case study in a middle-school geometry course. Computers \& Education, 145, 103734.

Irawati, T. (2019, March). Pembelajaran IPA SD Menggunakan Metode Eksperimen Untuk Menumbuhkan Semangat Belajar Siswa. In Seminar Nasional Pendidikan Dasar (Vol. 1, No. 01).

Jamaluddin, D., Ratnasih, T., Gunawan, H., \& Paujiah, E. (2020). Pembelajaran daring masa pandemik Covid-19 pada calon guru: hambatan, solusi dan proyeksi. $L P 2 M$.

Jauhariyyah, F. R. A., Suwono, H., \& Ibrohim, I. (2018, February). Science, technology, engineering and mathematics project based learning (STEM-PjBL) pada pembelajaran sains. In Seminar Nasional Pendidikan IPA 2017 (Vol. 2).

Karim, A. (2016). Pembaharuan pendidikan Islam multikulturalis. Jurnal Pendidikan Agama Islam -Ta'lim, 14(1), 19-35. Retrieved from http://jurnal.upi.edu/taklim/view/3880/pemb aharuan-pendidikan-islam-multikulturalis$\underline{\text { html }}$

Khairunisa, R. (2017). Penggunaan Media Berbasis Teknologi Informasi dan Komunikasi (TIK) dalam Peningkatan Kemampuan Menulis Puisi Siswa Kelas III B SDN 005 Awang Long Samarinda. PENDAS MAHAKAM: Jurnal Pendidikan Dasar, 2(1), 100-107

Kiili, C., Bråten, I., Kullberg, N., \& Leppänen, P. H. (2020). Investigating elementary school students' text-based argumentation with multiple online information resources. Computers \& Education, 147, 103785.

Lazonder, A. W., Walraven, A., Gijlers, H., \& Janssen, N. (2020). Longitudinal assessment of digital literacy in children: Findings from a large Dutch single-school study. Computers \& Education, 143, 103681

Lestariningrum, A. (2014). Pengaruh Penggunaan Media VCD terhadap Nilai-Nilai Agama dan 
Moral Anak. Jurnal Pendidikan Usia Dini, 8(2), 195-206.

Marziali, M. E., Card, K. G., McLinden, T., Wang, L., Trigg, J., \& Hogg, R. S. (2020). Physical distancing in COVID-19 may exacerbate experiences of social isolation among people living with HIV. AIDS and Behavior, 1.

Pakpahan, R., \& Fitriani, Y. (2020). Analisa Pemanfaatan Teknologi Informasi Dalam Pembelajaran Jarak Jauh Di Tengah Pandemi Virus Corona Covid-19. Journal of Information System, Applied, Management, Accounting and Research, 4(2), 30-36.

Parasyanti, N. K. V., Yanti, N. L. G. P., \& Mastini, I. G. A. A. P. (2020). Pendidikan Kesehatan Cuci Tangan Pakai Sabun dengan Video Terhadap Kemampuan Cuci Tangan pada Siswa SD. Jurnal Akademika Baiturrahim Jambi, 9(1), 122-130.

Patandung, Y. (2017). Pengaruh model discovery learning terhadap peningkatan motivasi belajar IPA Siswa. Journal of Educational Science and Technology (EST), 3(1), 9-17.

Permatasari, H. I. (2018). Penerapan pendekatan STEM (science, technology, engineering and mathematic) untuk meningkatkan aspek kognitif peserta didik pada materi alat-alat optik (Doctoral dissertation, UIN Sunan Gunung Djati Bandung).

Pertiwi, C.S.R, Rochman, C., and Mansyur, A.S. (2019). Analsisi Tantangan Ketercapaian Indikator Standar Penilaian. Halaqa: Islamic Education Journal. 3(1). DOI: https://doi.org/10.21070/halaqa.v3i1.2018

Praherdhiono, H., Adi, E. P., Prihatmoko, Y., Nindigraha, N., Soepriyanto, Y., Indreswari, H., \& Oktaviani, H. I. (2020). Implementasi Pembelajaran di Era dan Pasca Pandemi Covid-19. Seribu Bintang.

Prayogi, R. D. (2020). Kecakapan Abad 21: Kompetensi Digital Pendidik Masa Depan. Manajemen Pendidikan, 14(2).

Pujiati, A. (2019). Peningkatan Literasi Sains dengan Pembelajaran STEM Di Era Revolusi Industri 4.0. Diskusi Panel Nasional Pendidikan Matematika, 5(1).

Pujilestari, Y. (2020). Dampak Positif Pembelajaran Online Dalam Sistem
Pendidikan Indonesia Pasca Pandemi Covid19. 'ADALAH, 4(1).

Purwanto, A., Pramono, R., Asbari, M., Hyun, C. C., Wijayanti, L. M., \& Putri, R. S. (2020). Studi Eksploratif Dampak Pandemi COVID19 Terhadap Proses Pembelajaran Online di Sekolah Dasar. EduPsyCouns: Journal of Education, Psychology and Counseling, 2(1), 1-12.

Priatna, T., Baihaqi, W., Rahman, A., \& Sunarya, Y. (2020). Reformulasi tugas dan fungsi guru menghadapi tantangan pendidikan era revolusi industri 4.0. Karya Tulis Ilmiah (KTI) Masa Work From Home (WFH) Covid-19 UIN Sunan Gunung Djati Bandung, 1-13.

Qadir, J., \& Al-Fuqaha, A. (2020). A Student Primer On How to Thrive in Post-COVID19 Engineering Education.

Rochman, C dan Rokayah (2019). Challenges In Science Technology Engineering And Math (STEM) Learning In Elementary Schools Based on Literacy Of Social Science. Journal of Physics: Conference Series. 1318 (012049).DOI:10.1088/1742$6596 / 1318 / 1 / 012049$

Rostikawati, Y., Aeni, E. S., \& Wuryani, W. (2020). Peran Guru Dalam Membentuk Karakter Siswa Melalui Pembelajaran Kesantunan Berbahasa Di Media Sosial. Abdimas Siliwangi, 3(1), 112-120.

Sai, M. (2017). Pengaruh Model Pembelajaran Group Investigation Berbasis Internet Terhadap Hasil Belajar Dan Kemampuan Digital Literasi Siswa Pada Pembelajaran IPS. Jurnal Penelitian Pendidikan, 34(1), 3754.

Sandars, J., Correia, R., Dankbaar, M., de Jong, P., Goh, P. S., Hege, I., ... \& Webb, A. (2020). Twelve tips for rapidly migrating to online learning during the COVID-19 pandemic. MedEdPublish, 3068.

Sanjaya, R. (Ed.). (2020). 21 Refleksi Pembelajaran Daring di Masa Darurat. SCU Knowledge Media.

Sarnita, F., \& Fitriani, A. (2019). Pengembangan Perangkat Pembelajaran Model PBL Berbasis STEM untuk Melatih Keterampilan 
Berfikir Kreatif Siswa Tuna Netra. Jurnal Pendidikan MIPA, 9(1), 38-44.

Satriah, L., Miharja, S., Setiana, W., \& Rohim, A. S. (2020). Optimalisasi bimbingan online dalam upaya mencegah penyebaran virus Covid-19 pada Fakultas Dakwah dan Komunikasi, UIN SGD Bandung.

Setiawan, A. R. (2020). Lembar Kegiatan Literasi Saintifik untuk Pembelajaran Jarak Jauh Topik Penyakit Coronavirus 2019 (COVID19).

Setiawan, A. R., \& Mufassaroh, A. Z. (2020). Lembar Kegiatan Siswa untuk Pembelajaran Jarak Jauh Berdasarkan Literasi Saintifik pada Topik Penyakit Coronavirus 2019 (COVID-19).

Sintema, E. J. (2020). Effect of COVID-19 on the Performance of Grade 12 Students: Implications for STEM Education. Eurasia Journal of Mathematics, Science and Technology Education, 16(7), em1851.

Subarto, S. (2020). Momentum Keluarga Mengembangkan Kemampuan Belajar Peserta Didik Di Tengah Wabah Pandemi Covid-19. 'ADALAH, 4(1).

Surya, A. S. P., Rizal, F., \& M Pd, M. T. (2019). Hubungan Kemampuan Teknologi Informasi Komunikasi (Tik) Terhadap Hasil Belajar Menggambar Dengan Perangkat Lunak (MDPL) Siswa Kelas XI Jurusan Teknik Desain Pemodelan dan Informasi Bangunan (TDPIB) di SMK Negeri 1 Sumatera Barat. CIVED (Journal of Civil Engineering and Vocational Education), 6(1).

Sutisna, E., Novita, L., \& Iskandar, M. I. (2020). Penggunaan Media Pembelajaran Berbasis Teknologi, Informasi, Dan Komunikasi Dalam Meningkatkan Hasil Belajar Subtema Lingkungan Tempat Tinggalku. Pedagonal: Jurnal Ilmiah Pendidikan, 4(1), 01-06.

Syamsuar, S., \& Reflianto, R. (2019). Pendidikan dan tantangan pembelajaran berbasis teknologi informasi di era revolusi industri 4.0. E-Tech: Jurnal Ilmiah Teknologi Pendidikan, 6(2).

Tran, T., Hoang, A. D., Nguyen, Y. C., Nguyen, L. C., Ta, N. T., Pham, Q. H., ... \& Nguyen, T. T. (2020). Toward Sustainable Learning during School Suspension: Socioeconomic,
Distance Learning During The Covid-19 Pandemic

Occupational Aspirations, and Learning Behavior of Vietnamese Students during COVID-19. Sustainability, 12(10), 4195.

Wang, G., Zhang, Y., Zhao, J., Zhang, J., \& Jiang, F. (2020). Mitigate the effects of home confinement on children during the COVID19 outbreak. The Lancet, 395(10228), 945947.

Widiyaningrum, W., \& Harnanik, H. (2016). Faktor-Faktor yang Mempengaruhi Kreativitas Belajar Siswa Kelas XII Pemasaran Pada Pembelajaran Produktif Pemasaran di SMK Negeri 1 Purbalingga. Economic Education Analysis Journal, 5(3), 729-729.

Yamin, M., \& Syahrir, S. (2020). Pembangunan Pendidikan Merdeka Belajar (Telaah Metode Pembelajaran). Jurnal Ilmiah Mandala Education, 6(1).

Yazdi, M. (2012). E-learning Sebagai Media Pembelajaran InteraktifBerbasis Teknologi Informasi. In FORISTEK: Forum Teknik Elektro dan Teknologi Informasi (Vol. 2, No. 1).

Zainuddin, Z., Irawati, E., Misbah, M., \& Dewantara, D. (2020, January). Developing of natural science teaching materials character-based in science technology and society (STS) approach. In Journal of Physics: Conference Series (Vol. 1422, No. 1, p. 012013). IOP Publishing. 